\title{
PENGEMBANGAN EARLY WARNING SYSTEM UNTUK DELISTING SAHAM SYARIAH MENGGUNAKAN SUPPORT VECTOR MACHINE (SVMs)
}

\author{
Zulnan Tinggi Hari ${ }^{1}$, Sakum² \\ ${ }^{1}$ Budiandru Accounting and Sharia Consultant, zulnan26@gmail.com \\ 2 STAI Pelita Bangsa, mr.sakum@yahoo.co.id
}

A R T I C L E I N F O

Article history:

Received : 15/11/2020

Revised : 18/11/2020

Accepted : 19/11/2020

Key words:

EWS, Delisting, Early Warning System, Syariah Stock, Support Vector Machine (SVMs).

DOI:

doi.org/10.37366/jespb.v5i02.117

\begin{abstract}
A B S T R A C T
This study aim to produce Early Warning System in predicting the occurrence of delisting in Islamic stocks by using Support Vector Machines (SVM). The sample used in this research are companies listed on the Indonesian Syariah Stock Index (ISSI) for the period of $2012-2018$. With the variables used in this research: Turn Over Asset, Long Term Debt, Interest Coverage, Debt to Equity, Quick Ratio, ROA, ROE Leverage, Current Ratio, ROIC. The population of this study is 335 Islamic stocks registered with ISSI. There are 102 companies which consists of listed and delisted companies from sharia shares as comparison for the sample data. The Method applied in this study is Purposive Sampling for The sampling technique. From the result found that accuracy rate of the best SVM models is SVM 4 models with 100\% accuracy.
\end{abstract}

\begin{abstract}
A B S T R A K
Tujuan dari penelitian ini adalah mengembangan model Early Warning System yang dapat mengantisiapsi terjadinya delisting pada saham syariah dengan Support Vector Machines. Pada perusahaan yang terdaftar pada Indeks Saham Syariah Indonesia (ISSI) pada periode 2012 - 2017. Dengan variable Keuanganl Debt to Equity, ROIC, Asset Turn Over, Quik Ratio, Current Ratio, ROA, ROE Leverage, Long Term Debt, Interest Coverage. Populasi dari penelitian ini adalah 335 saham syariah yang terdaftar pada ISSI pada periode 2012 - 2017. Sampel dalam penelitian ini sebanyak 102 perusahaan. Teknik pengambilan sampel yang digunakan dalam penelitian ini menggunakan Purposive Judgement Sampling. Sementara model yang digunakan dalam penelitian ini adalah Support Vector Machine.
\end{abstract}

\section{PENDAHULUAN}

Saham adalah surat bukti kepemilikan terhadap aset-aset perusahaan yang menerbitkan saham, dengan kepemilikan terhadap saham suatu perusahaan, maka seorang investor mempunyai hak terhadap pendapatan dan kekayaan perusahaan melalui deviden setelah dikurangi seluruh kewajiban perusahaan (Tandelilin, 2010). Fahmi (2012) menjelakan bahwa Saham sebagai tanda dan dasar adanya andil kepemilikan dalam suatu perusahaan dalam bentuk kertas yang memiliki nominal tertentu, nama dari perusahaan disertai dengan adanya aturan dalam hak dan kewajiban dari pemegang saham.

Pada asalnya harga saham dibentuk oleh mekanisme permintaan dan penawaran yang terhadi pasar modal, dimana investor mendapatkan informasi yang relevan tentang saham dan kondisi perusahaan sehingga dapat memberikan penilaian (Valuation) terhadap saham yang kemudian dari 
interaksi permintaan dan penawaran di pasar modal terciptalah nilai wajar (Fair Value) dari sebuah saham tanpa adanya intervensi yang secara artifisial dibuat untuk mempengaruhi harga saham. Namun salah satu distorsi terbesar yang kerap terjadi dalam penentuan harga saham adalah adanya manipulasi yang dilakukan para spekulan pasar terhadap harga saham. Manipulasi harga saham diartikan sebagai intervensi terhadap mekanisme pasar yang untuk mencegah terbentuknya nilai yang wajar (Fair Value) dari sebuah saham. Manipulasi juga diartikan sebagai upaya sengaja atau artifisial untuk mempengaruhi harga saham. Manipulasi harga saham berdampak pada penurunan tingkat kepercayaan investor dan calon investor terhadap pasar dan lebih jauh pasar akan kehilangan investor (Doganay \& R.Aktas, 2009).

Sebagai solusi terhadap kondisi pasar modal konvensional maka dilakukan upaya untuk diciptakan wadah investasi yang sesuai dengan prinsip syariah dengan didirikannya pasar modal syariah dan terbitnya saham syariah pada 3 Juli 1997. Kemudian pada tanggal 3 Juli 2000 diluncukannya Jakarta Islamic Index (JII) yang memfasilitasi produk-produk saham dan investasi lainnya dijalankan berdasarkan prinsip-prinsip syariah. JII menggunakan konsep syariah dalam dalam penentuan kriteria perusahaan yang dapat masuk kedalam emiten syariah. Selain itu JII berupaya untuk menciptakan praktik perdagangan saham yang terbebas dari segala bentuk muamalah yang bertentangan dengan syariah seperti menjual barang-barang yang haram, unsur penipuan, riba dan gharar (Rita, 2009).

Kapitalisasi Saham syariah terus mengalami pertumbuhan. Berdasarkan data dari OJK Pada penutupan bursa 2014, Indeks Saham Syariah Indonesia (ISSI) meningkat 17,35\% ke level 168,64 dan nilai kapitalisasi pasar sahamnya meningkat 15,21\% menjadi sebesar Rp2.946,9 triliun atau sekitar 56,37\% dari total kapitalisasi pasar saham. Pada periode yang sama, Jakarta Islamic Index (JII) mengalami peningkatan sebesar $18,10 \%$ ke level 691,04. Nilai kapitalisasi pasar saham JII juga meningkat 16,29\% dibandingkan akhir tahun 2013 menjadi sebesar Rp1.944,5 triliun atau sekitar $37,19 \%$ dari total kapitalisasi pasar saham.

Terhitung sejak 3 Juli 1997 telah terbit saham syariah dan Screening saham syariah di Indonesia yang menghasilkan indeks saham ISSI (Indonesia Sharia Stock Index). Pada ISSI Saham-saham yang masuk ke dalam indeks ini hanyalah saham yang memenuhi kriteria saham syariah sesuai ketentuan yang ditetapkan Dewan Syariah Nasional dan bursa efek. Saham-saham syariah haruslah sesuai dengan standart kriteria kuantitatif dan kriteria kualitatif. Dari seluruh saham yang terdapat pada ISSI terdapat indeks lainnya yakni JII (Jakarta Islamic Index) yang terdiri atas 30 saham ISSI dengan kinerja terbaik (Firmansyah, 2017).

Masyarakat memiliki respon dan ekspektasi yang baik terhadap pertumbuhan perusahan yang terdaftar dalam emiten saham syariah, hal itu dibuktikan dengan kapitalisasi Saham syariah terus mengalami pertumbuhan yang menunjukkan tingginya peran serta masyarakat. Berdasarkan data dari Statistik OJK Kapitalisasi saham syariah terus mengalami peningkatan yang signifikan tercatat dalam data statistik OJK pada tahun 2012 total kapitalisasi saham syariah sebesar 2,4 Triliun meningkat menjadi 3,5 Triliun atau sebesar pada akhir tahun 2017 yakni meningkat 43\% selama 5 
tahun. Jumlah saham syariah terus berkembang dari 304 saham pada tahun 2012 menjadi 359 saham pada tahun 2017 terjadi peningkatan sebesar 18\% dalam kurun lima tahun terakhir (Statistik OJK, 2017).

(Grafik Pertumbuhan Jumlah Saham Syariah)

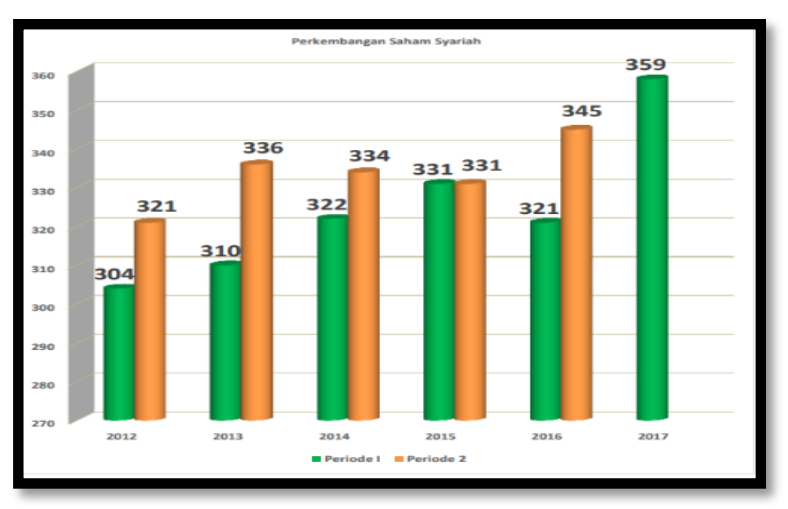

Komposisi saham syariah terus mengalami perubahan, dalam kurun lima tahun terakhir telah terakumulasi 249 saham baru atau $74 \%$ dari total saham syariah dan terdapat 220 saham yang telah mendapat status delisting dari ISSI yakni mencapai dari total saham syariah. Jumlah ini cukup signifikan dan membuka kemungkinan adanya trend peningkatan pada semester-semester kedepan bahwa jumlah saham yang akan mengalami delisting dari indeks saham syariah Indonesia akan semakin tinggi.

Terjadinya perubahan komposisi saham dan delisting saham merupakan salah satu resiko bagi investor yang secara khusus hanya menginginan investasi yang sesuai dengan prinsip-prinsip islam. Ketidakmampuan dalam menyeleksi saham yang tepat akan membawa resiko pada diterpilihnya saham-saham yang tidak memiliki kinerja finansial yang baik dan pada akhirnya mengalami delisting dari saham syariah terutama bagi lembaga keuangan syariah non perbangkan yang dana investasinya beroirentasi pada efek syariah seperti sukuk, dana reksa syariah dan khususnya saham syariah (Takaful Annual Report, 2016).

Terdapat beberapa judul penelitian terdahulu tentang delisting saham Hadi \& Anggreani (2008) sebagaimana juga Fatmawati (2012) dengan penelitiannya menggunakan analisis Zmijewski Model, The Altman Model dan The Springate Model yang ketiganya merupakan analisis prediksi kebangkrutan. Sementara Hwang (2014) dengan penelitian faktor informasi finansial dan non finansial dalam memprediksi status delisting pada suatu saham. Zhou, Ligang (2013) dalam penelitiannya tentang perbandingan model prediksi delisting. Hwang \& Shun (2014) dengan penelitian tentang pengembangan model prediksi pada saham Logistic Regression. Fungacova (2011) Yiannoulis (2016) Thitivadee (2016) Benny (2016) yang menjelaskan tentang factor-faktor yang mempengaruhi terjadinya delisting saham.

Dengan cukup tingginya frekuensi delisting dan perubahan komposisi saham pada saham syariah maka kebutuhan akan adanya early warning system (EWS) yakni sebuah system yang berfungsi sebagai pendeteksian sejak dini, menjadi sesuatu yang dibutuhkan. Karenanya penelitian ini berupaya untuk mengembangkan EWS untuk potensi resiko terjadinya delisting pada saham syariah dengan menggunakan model Machine Learning SVMs (Support Vector Machine) yakni sebuah model algoritma yang mengimplementasikan structural risk minimization yang bertujuan memperkecil tingkat kekeliruan (error) (Anwar, 2015). Bahwa diharapkan resiko terjadinya delisting dapat dihindari dengan adanya EWS karena potensi resiko tersebut mampu di deteksi sejak awal. 


\section{KAJIAN TEORI}

Sistem Peringatan Dini (Early Warning System) adalah serangkaian sistem yang berfungsi untuk memberitahukan akan timbulnya suatu kejadian, dapat berupa kejadian alam mapun sosial. Peringatan dini pada aktivitas memberikan informasi dengan bahasa yang mudah difahami (Duwipa, 2013) Model Sinyal dapat dianggap sebagai bentuk analisa trend, karenanya EWS merupakan pengembangan dari bentuk teori sinyal. Model EWS pada awalnya dikembangkan untuk mengantisipasi terjadinya krisis dalam bidang ekonomi sebagaimana penelitian yang dilakukan oleh Kaminsky and Reinhart (1999), Kaminsky, Lizondo, and Reinhart (1998), Berg and Patillo (1999), Goldstein, Kaminsky, and Reinhart (2000), Edison (2000) and Berg et al. (2004). Pada umumnya penelitian terdahulu menggunakan model probit dan logit dalam pengembangan EWS.

Teori Signal diungkapkan oleh Ross (1977) yang mengatakan bahwa manajemen perusahaan menjadi pihak yang diuntungkan dengan informasi yang mereka miliki dan diperioritaskan diberikan kepada investor. Adanya informasi terutama terkait dengan kinerja perusahaan yang mencerminkan prospek dimasa yang akan datang untuk dapt menaikkan harga saham perusahaan. Informasi merupakan alat penting bagi investor, melalui informasi dapat diketahui gambaran mengenai keadaan perusahaan baik saat ini, masa lalu, atapun prospek masa depan perusahaan. Informasi yang yang tersedia harus relevan, akurat, tepat waktu, dan lengkap adalah hal penting yang harus dimiliki investor sebagai alat analisis dalam keputusan investasi dipasar modal. Melalui publikasi informasi atau informasi yang diumumkan di media nantinya akan dijadikan oleh investor sebagai sinyal buruk atau sinyal baik pada upaya keputusan investasi. Reaksi pasar pada saat pengumuman tersebut diterima adalah hal yang diharapkan ketika pengumuman tersebut mengandung sinyal yang baik (Jogiyanto, 2000).

Volume perdagangan saham akan mencerminkan reaksi pasar. Perusahaan memiliki ekspektasi lebih baik dimasa depan, apabila dalam informasi yang disampaikan tersebut terdapat sinyal baik. Dampaknya investor menjadi tertarik untuk melakukan perdagangan saham. Hal tersebut tercermin dari perubahan volume perdagangan saham dimana reaksi pasar adalah positif. Efisiensi pasar akan memperlihatkan hubungan antara informasi yang dipublikasikan terkait informasi berupa laporan keuangan, politik, lingkungan, dan sosial terhadap fluktuasi volume perdagangan saham.

Tumuri (2011) menjelaskan delisiting diartikan sebagai proses dikeluarkannya saham yang terdaftar dari indeks atau daftar saham tertentu. Terdapat dua jenis delisting yakni voluntary delisting dan involuntary delisting. Pada voluntary delisting suatu perusahaan secara sengaja atau atas keinginan mereka sendiri mengeluarkan saham mereka dari indeks pasar modal atau bursa saham yang diperdagangkan. Sementara dalam involuntary delisting atau disebut juga compulsory delisting yakni dikeluarkannya suatu saham dari indeks pasar modal bukan atas keputusan perusahaan penerbit saham. keputusan dikeluarkannya saham suatu perusahaan dari indeks saham diambil oleh otoritas pasar modal berdasarkan peraturan yang ditetapkan. 
(SVMs) atau dikenal juga sebagai Support Vector Networks adalah model pembelajaran tersupervisi (Supervised Learning Models) yang terasosiasi dengan algoritma pembelajaran (Learning Algorithm) yang digunakan dalam analisa data dengan cara klasifikasi dan regresi (Cortes \& Vapnik, 1995). Sementara Olson dan Delen (2008) mendefinisikan SVMs sebagai Supervised Learning Methods atau metode pembelajaran tersupervisi yang menghasilkan fungsi pemetaan input-output (Input-Output Mapping Function) yang diambil dari data latihan yang telah terlabelisasi. Mapping yang dilakukan oleh SVM terbagi menjadi dua yakni 1) fungsi klasifikasi yang berguna untuk membuat kategorisasi dari data, 2) fungsi regresi yang berguna untuk melakukan estimasi terhadap data tertentu.

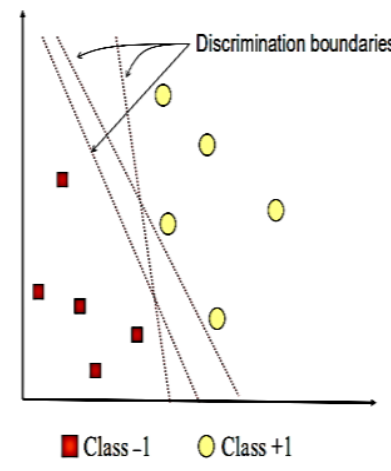

(a)

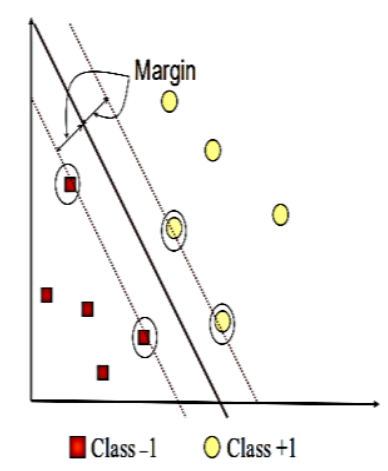

(b)
(Gambar Fungsi Hyper Plane)

Menurut Anwar (2015) SVMs pertamakali dikembangkan oleh Corter dan Vapnik pada tahun 1995. Model SVMs mengimplementasikan structural risk minimization yang berupaya memperkecil tingkat kekeliruan (error), dan generalisasi yaitu kemampuan untuk memperoleh tingkat kekeliruan yang kecil pada data test. Nugroho et al (2003) Konsep SVM secara sederhana dapat dijelaskan sebagai upaya mencari hyperplane terbaik dimana hyperplane berfungsi sebagai pemisah dua buah class dalam input space. Lihat Pada gambar terdapat dua buah class yakni +1 dan -1 . Pada pattern class 1 menggunakan symbol kotak merah dan pattern pada class +1 menggunakan symbol lingkaran kuning. Persoalan yang dipecahkan dalam algoritma SVMs adalah memsahkan antara class +1 dan class - 1 dengan mencari hyperplane atau pemisah yang terbaik. Terdapat beberapa garis pemisah yang disebut Discrimination boundaries dimana algoritma mencari garis pemisah terbaik atau hyperplane.

\section{Variabel Penelitian}

ROA, ROE, Leverage, Debt to Equity, Quick

Ratio, Current Ratio, ROIC, Asset Turn Over,Long Term Debt, Interest Coverage

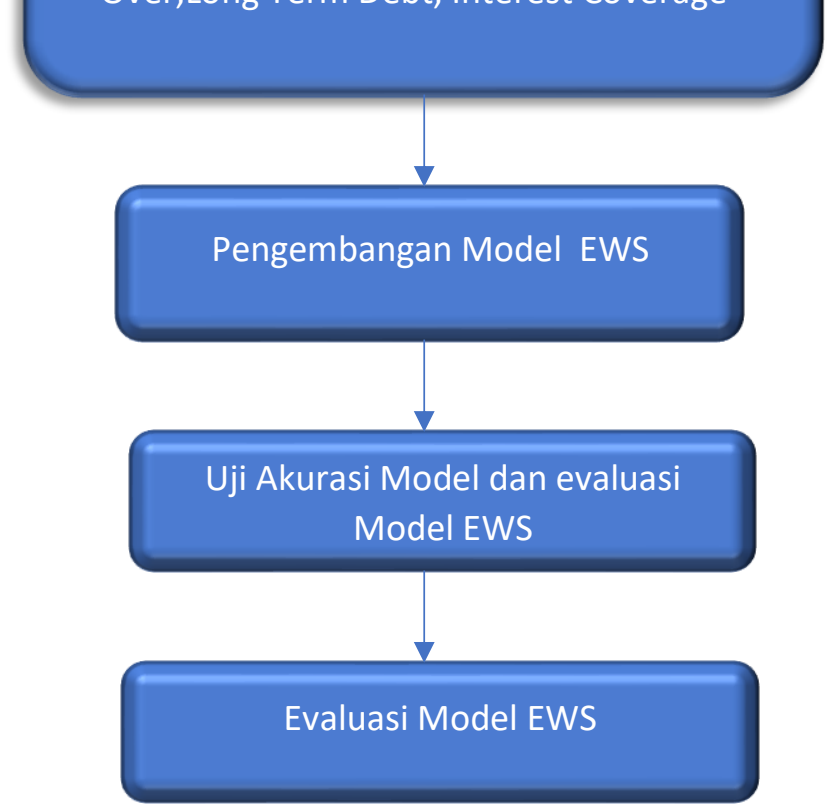

Berdasarkan kerangka penelitian dijelaskan bahwa penelitian ini memfokuskan diri pada pengembangan model Early Warning System yang didasarkan pada variabel-variabel keuangan dalam memprediksi dan mengantisipasi potensi terjadinya delisting menggunakan model SVMs. Dimana 
model-model SVMS yang dikembangkan akan diperbandikan dan dievaluasi berdasarkan tingkat akurasi model, dengan membandingkan antara hasil peramalan dan data actual.

\section{METODE PENELITIAN}

Penelitian ini menggunakan metode developmental sementara Paradigma dalam penelitian adalah paradigma kuantiatif yakni penelitian yang melibatkan variabel yang bersifat kuantitas (Sugiyono, 2011). Populasi dalam penelitian ini adalah perusahaan yang tergabung dalam Indeks Saham Syariah Indonesia (ISSI) 2012 sampai dengan 2017. Metode "Purposive Judgment sampling" Adalah pemilihan sampel yang didasarkankan pada penilaian karakteristik anggota populasi dan disesuaikan dengan tujuan dari penelitian (Kuncoro, 2003: 119). Sampel yang digunakan adalah 102 emiten saham syariah terdiri atas emiten dikeluarkan dari indeks ISSI (Delisted) dan saham yang masih terdaftar (Listed).

Variabel independen di istilahkan juga dengan variabel stimulus, predictor, antecedent yang dalam bahasa Indonesia dikenal dengan istilah variabel bebas.Variabel independen adalah variabel yang menyebabkan adanya perubahan pada variabel dependen ( Sugiono, 2011). Variabel bebas dalam penelitian ini adalah

\begin{tabular}{|l|l|}
\hline \multicolumn{2}{|c|}{ INDEPENDENT VARIABLES } \\
\hline Liquidity Ratio & $\begin{array}{l}\text { Current Asset / Current } \\
\text { X1 Current Ratio } \\
\text { X2 Quick Ratio } \\
\text { Current Asset - Inventory / } \\
\text { Current liabilities } \\
\text { (Cash + Marketable Securities) } \\
\text { / Current Liabilities }\end{array}$ \\
\hline $\begin{array}{l}\text { Solvability Ratio } \\
\text { X3 Total Debt to Total } \\
\text { X4 Debt to Equity Ratio } \\
\text { X5 Interest Coverage } \\
\text { X6 Long Term }\end{array}$ & $\begin{array}{l}\text { Total Debt / Total Asset } \\
\text { EBIT/Interest Expense }\end{array}$ \\
\hline Rentability Ratio & Long Term Debt/Total Asset \\
\hline
\end{tabular}

\begin{tabular}{|c|c|}
\hline $\begin{array}{l}\text { X7 Return on Asset } \\
\text { X8 Return on Equity } \\
\text { X9 Rerturn on Invested } \\
\text { Capital }\end{array}$ & $\begin{array}{l}\text { EAT / Total Asset } \\
\text { EAT/ Equity } \\
\text { EAT/ Invested Capital }\end{array}$ \\
\hline $\begin{array}{l}\text { Activity Ratio } \\
\text { X10 Asset Turnover }\end{array}$ & Sales / Total Asset \\
\hline
\end{tabular}

Support vector machine adalah metode analisis data yang secara sederhana dapat dijelaskan sebagai upaya mencari hyperplane terbaik dimana hyperplane berfungsi sebagai pemisah dua buah class dalam input space (Nugroho et all, 2003).

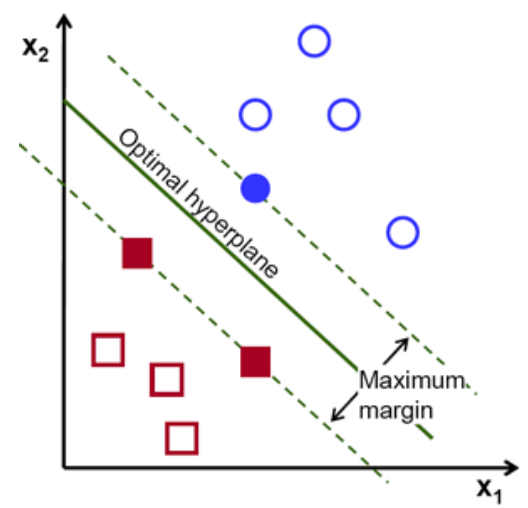

Menurut santosa (2007) support SVMs dapat digunakan untuk melakukan prediksi baik menggunakan regresi maupun klasifikasi. Anwar (2015) kemampuan SVMs melakukan prediksi dapat dijelaskan dapat dinotasikan dengan persamaan:

$$
y_{i}=w_{1} \phi_{1}(x)+b
$$

$$
\begin{array}{ll}
y_{i}= & \text { besaran skalar } \\
\phi_{1}(x)= & \text { fitur ruang dari } x \text { input } \\
w_{1} & =\text { nilai taksiran koefisien dengan prinsip } \\
& \text { struktural risk minimization }
\end{array}
$$

Berikut ini adalah langkah-langkah dalam analisis Support Vector Machines (SVMs):

\section{1) Input Variabel}

Yakni melakukan pengiputan variabel berupa data-data yang terkait dinama variabel terdiri atas $x_{1}=$ ROA (Return Of Asset) $x_{2}=$ ROE (Return of Equity), $x_{3}=$ Leverage, $x_{4}=$ Debt to Equity, $x_{5}=$ 
Growth, $x_{6}=$ Liquidity Ratio, $x_{7}=$ Share Liquidity, $x_{8}=$ Asset Turn Over, $x_{9}=$ NWCTA, $x_{10}=$ Firm Size

\section{2) Penentuan Tipe Variabel}

Menentukan tipe variabel baik variabel input maupun variabel output dimana variabel input adalah tipe data rasio atau data kontiniu dan variabel ouput adalah tipe data kategori.

\section{3) Melakukan Analisis dan prediksi.}

Pada tahap ini input data yang ada akan dioleh menggunakan algoritma Support Vector Machines untuk menghasilkan model prediksi yakni penentuan tipe kernel yang gunakan dalam SVMs, jumlah support vector yang digunakan dan support vector perkelas yang digunakan.

4) Evaluasi Akurasi Model.

Yakni melakukan evaluasi dari akurasi model SMVs dengan membandingkan Antara data aktual dan hasil prediksi yang dihasilkan oleh analisis. Dari perbandingan Antara nilai prediksi dan data actual akan diperoleh tingkat akurasi dari model yang digunakan berupa tingkat kecocokan antara prediksi dan data actual.

Adapun aplikasi yang digunakan untuk analisis menggunakan Support Vector Machine adalah Software Statistica Versi 12 yang dikelompokkan sebagai metode Data Mining.

\section{HASIL DAN PEMBAHASAN}

Pada penelitian ini dikembangkan 4 model Early warning system menggunakan Support Vector Machine. Keempat model tersebut dibedakan berdasarkan Kernel Type, Gamma level, Number Support Vector, Support Vector Perclass dan Number of Seed. Dari perbedaan spesifikasi masing masing model SVMs akan diuji tingkat akurasi prediksi dari model terhadap data.

Perbandingan Spesifikasi Model SVM

\begin{tabular}{|c|c|c|c|c|}
\hline Model & Kernel Type & $\begin{array}{c}\text { Number Support } \\
\text { Vectors }\end{array}$ & $\begin{array}{c}\text { Support } \\
\text { vectors per } \\
\text { class }\end{array}$ & Seed \\
\hline SVM 1 & Linear $(\mathrm{nu}=0.700)$ & $59(54$ bounded $)$ & $30(0), 29(1)$, & 2000 \\
\hline SVM 2 & $\begin{array}{c}\text { Radial Basis function } \\
\text { gamma }=0.100\end{array}$ & $50(46$ bounded $)$ & $25(0), 25(1)$, & 1000 \\
\hline SVM 3 & Linear $($ nu $=0.500)$ & $42(34$ bounded $)$ & $22(0), 20(1)$, & 1500 \\
\hline SVM 4 & $\begin{array}{c}\text { Radial Basis function } \\
\text { gamma }=12.00\end{array}$ & $61(11$ bounded $)$ & $27(0), 34(1)$ & 2000 \\
\hline
\end{tabular}

Model SVM 4 memiliki Gamma = 12 yang lebih besar dari model SVM $2=0.1$. Sementara untuk support vector per class pada model untuk class (1) model SVM 4 jauh lebih tinggi dari model-model lainnya yakni sebesar 34. Karena model-model sebelumnya cukup akurat dalam memprediksi class (0) namun tidak cukup akurat dalam memprediksi class (1). Dengan penambahan jumlah support vector pada class (1) tingkat akurasi prediksi pada class (1) meningkat menjadi 100\%. Selain itu jumlah Seed juga mempengaruhi tingkat akurasi prediksi, SVM 4 memiliki jumlah Seed 2000 dua kali lebih banyak dari SVM 2 yang hanya terdiri atas 1000 Seed.

Dari hasil pengujian tingkat akurasi dari keempat model SVM yang telah dikembangkan maka dapat dilakukan perbandingan tingkat akurasi pada setiap model.

\begin{tabular}{|l|c|l|c|l|c|l|c|}
\hline \multicolumn{7}{|c|}{ PERBANDINGAN AKURASI MODEL SVM } \\
\hline & $\begin{array}{c}\text { Class } \\
\text { All }\end{array}$ & & $\begin{array}{c}\text { Class } \\
\text { All }\end{array}$ & & $\begin{array}{c}\text { Clas } \\
\text { s All }\end{array}$ & \multicolumn{2}{|c|}{ MODODL SVM 4 } \\
\hline Total & 102 & Total & 102 & Total & 102 & Total & 102 \\
\hline Correct & 73 & Correct & 74 & Correct & 84 & Correct & 102 \\
\hline Incorrect & 29 & $\begin{array}{l}\text { Incorre } \\
\text { ct }\end{array}$ & 28 & $\begin{array}{l}\text { Incorre } \\
\text { ct }\end{array}$ & 18 & $\begin{array}{l}\text { Incorre } \\
\text { ct }\end{array}$ & 0 \\
\hline $\begin{array}{l}\text { Correct } \\
(\%)\end{array}$ & 71.57 & $\begin{array}{l}\text { Correct } \\
(\%)\end{array}$ & 72.55 & $\begin{array}{l}\text { Correct } \\
(\%)\end{array}$ & 82.35 & $\begin{array}{l}\text { Correct } \\
(\%)\end{array}$ & 100.00 \\
\hline $\begin{array}{l}\text { Incorrect } \\
(\%)\end{array}$ & 28.43 & $\begin{array}{l}\text { Incorre } \\
\text { ct (\%) }\end{array}$ & 27.45 & $\begin{array}{l}\text { Incorre } \\
\text { ct (\%) }\end{array}$ & 16.56 & $\begin{array}{l}\text { Incorre } \\
\text { ct (\%) }\end{array}$ & 0.00 \\
\hline
\end{tabular}

(Tabel Perbandingan Akurasi Model SVM) 
Dari tabel komparasi tingkat akurasi dari setiap model SVM kita ketahui bahwa masing masing model memiliki tingkat akurasi yang berbeda dimana standar dalam penilaian tinggi rendahnya akurasi yang dimiliki oleh setiap model ditentukan oleh seberapa besar persentase kesesuaian Antara prediksi dan data aktual yang dinyatakan dengan persentase correct dan seberapa kecil tingkat kekeliruan dalam prediksi yakni kekeliruan antara prediksi dan data aktual yang dinyatakan dengan persentase incorrect.

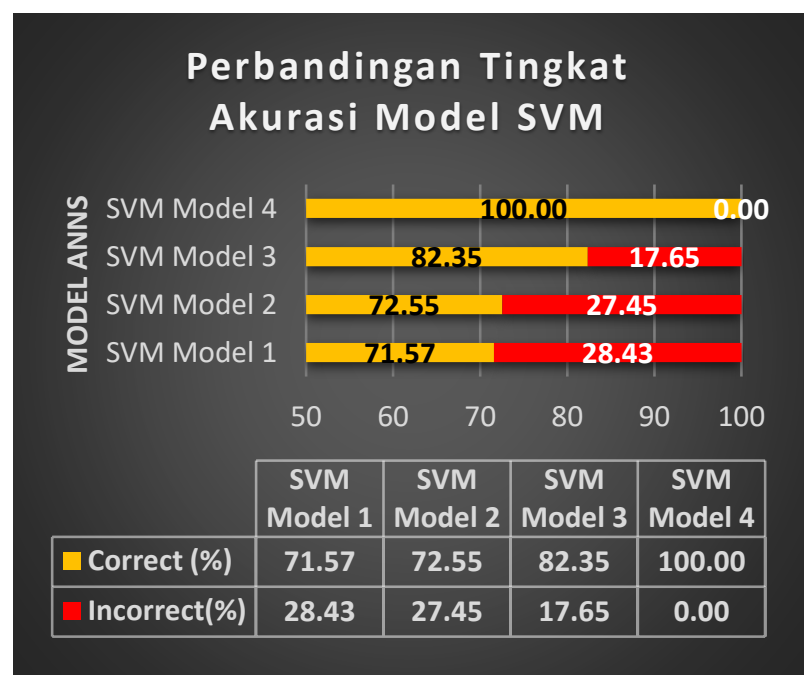

(Grafik Perbandingan Akurasi Model SVM)

Dari data dan grafik diketahui bahwa model SVM 4 memiliki tingkat akurasi yang paling tinggi dibandingkan model-model SVM lainnya yakni mencapai nilai 100\%. Dengan ini dapat disimpulkan bahwa kernel dengan tipe Radial basis function lebih akurat dalam memprediksi terjadinya delisting pada saham syariah. Dari perbandingan model SVM 2 dan SVM 4 dengan tipe kernel yang sama yakni Radial basis function diketahui bahwa nilai gamma yang tinggi berpengaruh terhadap daya akurasi prediksi model SVM, bahwa semakin nilai gamma yang digunakan maka semakin tinggi tingkat akurasi model. Selain itu jumlah support vector pada setiap class yang digunakan berpengaruh terhadap daya akurasi model bahwa pada modelmodel. Pada model-model SVM sebelumnya kecenderung memiliki banyak kekeliruan pada prediksi class (1) atau terjadinya delisting pada suatu saham.

\section{Prediksi model SVM Menggunakan Data Out of Sample}

Pada bagian ini akan dilakukan prediksi menggunakan data yang berasal dari luar sampel penelitian yang dikenal dengan istilah Out of Sample Data menggunakan data dari 30 perusahaan yang termasuk kedalam emiten ISSI pada semester I tahun 2018 yakni pada emiten yang tetap listing mapun yang telah mengalami delisting.

\begin{tabular}{|l|c|c|c|}
\hline \multicolumn{4}{|c|}{ Model SVM } \\
\hline & Status -0 & Status -1 & Status All \\
\hline Total & 10 & 20 & 30 \\
\hline Correct & 10 & 16 & 26 \\
\hline Incorrect & 0 & 4 & 4 \\
\hline Correct (\%) & 100.00 & 80 & 86.66 \\
\hline Incorrect (\%) & 0.00 & 20.00 & 14.44 \\
\hline
\end{tabular}

(Hasil Prediksi Out of Sample)

Dari tabel diketahui bahwa tingkat akurasi dari hasil prediksi mengunakan data out of sample yakni dengan total correct nilai pada status-1 sebesar 10 yakni $100 \%$ dan total correct nilai pada status-0 sebesar 26 atau $80 \%$ dan total incorrect sebesar 20\% sehingga diperoleh data total correct sebanyak 26 data atau $86.66 \%$ dan data incorrect sebesar 4 data atau $6.44 \%$.

\section{KESIMPULAN DAN SARAN}

Berdasarkan pembahasan dari hasil penelitian yang telah dilakukan dari model prediksi delisting pada saham syariah dalam Support Vector Machine 
(SVM) diperoleh beberapa kesimpulan sebagai berikut:

1) Disimpulkan juga bahwa variabel keuangan memiliki daya prediktif terhadap terjadinya delisting pada saham syariah dalam indeks ISSI. Pengaruh dari variabel bebas atau variabel prediktor yakni rasio keuangan terhadap variabel target atau variabel terikat yakni potensi terjadinya delisting pada saham syariah dalam indeks ISSI berbeda-beda pada masingmasing model yang digunakan dalam penelitian ini. Variabel keuangan pada rasio profitabilitas memiliki tingkat pengaruh tertinggi yakni pada rasio ROA, ROE dan ROI disusul variabel rasio likuiditas yakni pada current asset, Interest Coverage. Dengan kata lain faktor profitabilitas adalah yang dapat memprediksi terjadinya delisting.

2) Pada model SVM dikembangkan 4 model SVM dengan tingkat akurasi prediksi yang berbedabeda. Model SVM 1 dengan tingkat akurasi 71.57\%, Model SVM 2 dengan tingkat akurasi 72.55\%, Model SVM 3 dengan tingkat akurasi 82.35\% dan Model SVM 4 dengan tingkat akurasi $100 \%$. dapat disimpulkan bahwa model SVM 4 adalah model terbaik.

3) Dari hasil Prediksi Out of Sample diketahui bahwa tingkat prediksi dari model SVM 4 pada data yang berada diluar sampel adalah sebesar $86.44 \%$ artinya terdapat tingkat kekeliruan sebesar $14.66 \%$ dari data yang berada didalam sampel.

Adapun rekomendasi dan saran terhadap stakeholder yang terkait dengan tema penelitian ini adalah sebagai berikut:
1) Diharapkan pihak pemerintah dan swasta yang memiliki kecukupan sumberdaya baik finansial maupun SDM dapat melanjutkan pengembangan model prediksi ini menjadi menjadi sistem informasi yang bersifat otomatis dan aplikasi dengan interface yang mudah digunakan. Diharapkan penelitian dapat menjadi model awal dalam pengembangan early warning system yang akurat dalam memperdiksi terjadinya delisting pada saham syariah.

2) Diharapkan para investor untuk lebih berhatihati dalam memilih saham dan investasi syariah dan memperhatikan aspek finansial dari suatu saham tidak hanya dari sisi keuntungan namun juga dari sisi kesehatan keuangan yang berpengaruh pada keajegan dari status dari suatu saham pada indeks saham syariah.

\section{REFERENSI}

Duwipa, Fatra. "Sistem Peringatan Dini (Early Warning System)". Lembaga Penelitian \& Pengembangan Kesejahteraan Sosial LPPK. (2013).

Kaminsky, G. and C. Reinhart, (2000). "On Crises, Contagion, and Confusion"; Journal of International Economics; 51(1), pp. 145-68, June. Kaminsky, G., S. Lizondo and C. Reinhart (1998). "Leading Indicators of Currency Crises", IMF Staff Papers, 45, No. 1, pp. 1-48.

Kaminsky, G. and C. Reinhart (1999). “The Twin Crises: The Causes of Banking and Balance-ofPayments Problems", American Economic Review; 89(3), pp. 473-500, June.

Berg, A. and C. Pattillo (1999a). "Are Currency Crises Predictable? A Test" IMF Staff Papers; 46(2), June, pp. 107-38. 
Berg, A. and C. Pattillo (1999b). "Predicting Currency Crises: The Indicators Approach and an Alternative" Journal of International Money and Finance; 18(4), August, pp. 561-86.

Berg, A., E. Borenszstein and C. Pattilo (2004). "Assessing Early Warning Systems: How They Worked in Practice" IMF Working Paper, WP/04/52, March

Bhattacharya, Biswa Nath (2009) Early Warning System for Economic and Financial Risks in Kazakhstan,

https://www.researchgate.net/publication/22 8126986.

Fahmi, Irham (2012) Pengantar pasar modal, Panduan bagi para praktisi dan akademisi dalam memahami pasar modal Indonesia. Alfabeta. Bandung 2012.

M. Doganay, and R.Aktas, (2009) "Detecting stockprice manipulation in an emerging market: The case of Turkey," Expert Syst. Appl., vol. 36, no. 9, 2009, pp. 11944-11949.

Rio, Rita (2009). "Penerapan prinsip syariah di pasar modal": Telaah bisnis, Volume 10, No.1.

Firmansyah, Egi Arvian. (2017) Seleksi Saham Syariah: Perbandingan antara Bursa Efek Indonesia dan Malaysia, Jurnal Inspirasi Bisnis dan Manajemen, Vol 1, (1), 2017, 0.

Otoritas jasa Keuangan (2017), Perkembagan Pasar modal syariah: Sinergi Menuju Pasar Modal Syariah yang Lebih Besar dan Berkembang. Laporan Perkembangan pasar modal syariah.

Fatmawati, Mila. (2012) Penggunaan The Zmijewski Model, The Altman Model, Dan The Springate Model Sebagai Prediktor Delisting. Jurnal Keuangan dan Perbankan, Vol.16, No.1 Januari 2012, hlm. 56-65.
Hadi, Syamsul \& Anggraeni, Atika (2008) Pemilihan Prediktor Delisting Terbaik (Perbandingan Antara The Zmijewski Model, The Altman Model, Dan The Springate Model) Jurnal Akuntansi Dan Auditing Indonesia (Jaai)No.2 2008.

Hwang, Tae \& Kang, Sun Min \& Ji Jin, Shun (2014), A delisting prediction model based on nonfinancial information. Asia-Pacific Journal of Accounting \& Economics, 2014 Vol. 21, No. 3, 328-347.

Zhou, Ligang (2013) "Predicting the removal of special treatment or delisting risk warning for listed company in China with Adaboost", Procedia Computer Science 17 ( 2013) 633 - 640.

Fungacova, Zuzana. \& Hanousek, Jan (2011). Determinants of firm delisting on the prague stock exchange. Prague economic papers, 4, 2011.

Benny, Leslie \& Yanthi Hutagaol. (2016) Empirical Investigation Of Determinant Factors Of Company Delisting: Evidence From Indonesia. Journal of Applied Finance and Accounting, 6(1), 2566.

Hartono, Jogiyanto. (2008). Teori Portofolio Dan Analisis Investasi. BPFE,Yogyakarta.

Siddaiah, Thummuluri (2011) Financial Service, Dorling Kinderslay, Noida India.

Cortes, Corinna. And Vapnik, Vladimir (1995) Support-Vector Networks 1995 Kluwer Academic Publishers, Boston.

Anwar, saiful. Rohmansyah, dadang. Pramono, sigit. and Watanabe, kenji. (2010), Treating return of mudharabah time deposit as investment instrument A utilization of artificial neural networks (ANNs) Humanomics Vol. 26 No. 4, 2010 pp. 296-30.

Anwar, Saiful. (2015). "Handbook Of Research On 
Islamic Banking And Finance: An Introduction of design Science Research Metodology, An

Engineering Approach", C.V Penebar kata,

\section{Ciputat tangerang.}

